\title{
Nitrogen Fertilization and Inoculation Effects on Dry Bean
}

\author{
Ryan Buetow*, Grant H. Mehring, Hans Kandel, Burton Johnson, Juan M. Osorno \\ Department of Plant Sciences, North Dakota State University, Fargo, ND, USA \\ Email: ^ryan.buetow@ndsu.edu, grant.h.mehring@monsanto.com, hans.kandel@ndsu.edu, burton.johnson@ndsu.edu, \\ juan.osorno@ndsu.edu
}

How to cite this paper: Buetow, R., Mehring, G.H., Kandel, H., Johnson, B. and Osorno, J.M. (2017) Nitrogen Fertilization and Inoculation Effects on Dry Bean. Agricultural Sciences, 8, 1065-1081. https://doi.org/10.4236/as.2017.810077

Received: August 22, 2017

Accepted: October 8, 2017

Published: October 11, 2017

Copyright $(9) 2017$ by authors and Scientific Research Publishing Inc. This work is licensed under the Creative Commons Attribution International License (CC BY 4.0).

http://creativecommons.org/licenses/by/4.0/

\begin{abstract}
Dry bean (Phaseolus vulgaris L.) has the ability to form symbiotic relationships with $\mathrm{N}_{2}$-fixing bacteria. The research objectives were to evaluate yield and growth differences between dry bean cultivars from black, navy, and pinto market classes, with different $\mathrm{N}$ management combinations utilizing urea fertilizer, and two rhizobacteria inoculants. Research was conducted near Park River and Prosper, ND, during 2010, 2012, 2013. The experiment was a RCBD $3 \times 2 \times 3$ factorial with four replicates with three dry bean cultivars, two $\mathrm{N}$ fertility levels, and two rhizobacteria inoculum sources plus a non-inoculated treatment. The pinto cultivar was also evaluated in 2014. Results showed significant cultivar main effect differences for nodules per plant, vigor, height, and 1000 seed weight. The pinto cultivar had significantly more nodules per root (19) compared with the black (13) and navy cultivars (9). There were not significant differences between inoculant treatments. The fertilizer main effect indicated significant differences for vigor and 1000 seed weight. No significant interactions were detected among factors. Addition of $56 \mathrm{~kg} \mathrm{~N} \mathrm{ha}^{-1}$ resulted in more vigorous plants, but had no effect on seed yield, and reduced 1000 seed weight at harvest at Park River in 2013. Root nodule number was higher with the inoculant treatments with 16.2 and 15.8 nodules per plant compared to the non-inoculated treatment with 10.7 nodules per plant at Park River in 2013. The pinto variety Lariat with an application of $56 \mathrm{~kg} \mathrm{ha}^{-1}$ had visually greener plants in 2013 and 2014, except Park River in 2013, but SPAD readings were not following the same trend. Inoculation and application of $\mathrm{N}$ fertilizer on dry bean may not be necessary if rhizobacteria are present and soil $\mathrm{N}$ levels are sufficiently high but future research on rates, timing, and $\mathrm{N}$ source and appropriate strains of Rhizobia inoculant on other pinto varieties is suggested.
\end{abstract}

\section{Keywords}

Dry Bean, Rhizobacteria, Nitrogen, Legume 


\section{Introduction}

North Dakota dry bean (Phaseolus vulgaris L.) classes black, navy, and pinto averaged 33,600, 40,400, and 142,100 planted ha, respectively, from 2011 through 2015 which represents approximately 14\%, 18\%, and 62\% of total North Dakota planted hectares, respectively [1]. With $33 \%$ of the national planted hectares in 2017, North Dakota is the largest dry bean producing state followed by Michigan, Minnesota, Nebraska, and Idaho [1].

In North Dakota, the use of $\mathrm{N}$ fertilizer is recommended when the dry bean yield goal is greater than $2200 \mathrm{~kg} \mathrm{ha}^{-1}$, or the residual soil-N level is less than 56 $\mathrm{kg} \mathrm{ha}^{-1}$. Contrastingly, production recommendations are to inoculate the seeds with Rhizobium phaseoli bacteria if the yield goal is lower than $2200 \mathrm{~kg} \mathrm{ha}^{-1}$ and the residual $\mathrm{N}$ in the soil is less than $56 \mathrm{~kg} \mathrm{ha}^{-1}$ [2] [3]. On average, $95 \%$ of North Dakota and Minnesota dry bean farmers [4] apply $56 \mathrm{~kg} \mathrm{~N} \mathrm{ha}^{-1}$. Studies show that $\mathrm{N}$ increases the yield components number of pods per plant, number of seeds per pod, seed weight, and final grain yield expression [5]. Excessive $\mathrm{N}$ can increase lodging, inhibit nodule formation, delay maturity, and promote excessive leaf canopy growth [6]. Nitrogen is an essential nutrient for plant growth [7], and dry bean plants have been shown to fix between 22 and $90 \mathrm{~kg} \mathrm{~N} \mathrm{ha}^{-1}$, with an average of $44 \mathrm{~kg} \mathrm{ha}^{-1}$ [8]. Dry bean $\mathrm{N}_{2}$ fixation is generally considered lower than for faba bean (Vicia faba L.), field pea (Pisum sativum L.), and lentil (Lens culinaris Medik.) [9].

Nitrogen fixation alone may not provide enough $\mathrm{N}$ for a legume's needs throughout a growing season. However, $\mathrm{N}$ fertilizer application may reduce $\mathrm{N}_{2}$ fixation in root nodules [10]. A balance between soil available $\mathrm{N}$, application of $\mathrm{N}$ fertilizer and biological $\mathrm{N}_{2}$ fixation, may be required for optimal yields [11]. Assuming the right strain of Rhizobium is available in the soil, legume plants only make the energy investment required for symbiotic $\mathrm{N}_{2}$ fixation when there are short supplies of mineral $\mathrm{N}$ [12]. Since inoculation is inexpensive, environmentally friendly, and sustainable compared to supplemental $\mathrm{N}$ fertilizer applications, finding a way to consistently increase $\mathrm{N}_{2}$ fixation may benefit farmers. Graham [13] found that applications as low as $15 \mathrm{~kg} \mathrm{~N} \mathrm{ha}^{-1}$ may reduce rates of $\mathrm{N}_{2}$ fixation of dry bean by as much as $40 \%$. Compared with other legumes dry bean is not an efficient $\mathrm{N}_{2}$ fixing species and there appears to be a cultivar specificity in the strain of Rhizobia for nodulation [14].

Low and variable dry bean nodulation and $\mathrm{N}_{2}$ fixation have been attributed to many factors including, high temperature, drought, soil acidity [15], high soil residual N, a short growing season, seasonal weather variation [16] [17], and differences in growth habit between cultivars [10]. Edje et al. [10] researched the effect of six fertilizer levels $(0,40,80,120,160$, and $200 \mathrm{~kg} \mathrm{~N})$ on dry bean and reported that seed yield increased with addition of $40 \mathrm{~kg} \mathrm{~N} \mathrm{ha}^{-1}$ (2704) compared to the non-fertilized control $\left(2150 \mathrm{~kg} \mathrm{ha}^{-1}\right)$. However, $\mathrm{N}$ rates from 40 to $160 \mathrm{~kg}$ $\mathrm{N} \mathrm{ha}^{-1}$ produced similar seed yield and seed yield was only higher at the $200 \mathrm{~kg}$ $\mathrm{N} \mathrm{ha}^{-1}\left(3779 \mathrm{~kg} \mathrm{ha}^{-1}\right)$ rate compared to the $40 \mathrm{~kg} \mathrm{~N} \mathrm{ha}^{-1}$ rate. Leaf area index, 
total dry matter, and general plant vigor increased as $\mathrm{N}$ rate increased. Eckert et al. [18] conducted research on pinto bean cultivars and $\mathrm{N}$ fertilization. They reported that increasing $\mathrm{N}$ level did not influence seed yield or seed weight.

According to Kellman et al. [19], most soils sown to dry bean contain indigenous rhizobia. However, their results found that it should be possible to increase nodulation and seed yield of dry beans by combining suitable cultivars with an appropriate strain of rhizobia. Fageria et al. [20] reported that inoculation with a mixture of three Rhizobium tropici strains improved dry bean grain yield. Work done by Weiser et al. [21] observed dry bean nodulation in Fargo, ND on soil that had not previously been grown to dry bean or been inoculated. The study found that nodulation can be enhanced by inoculation of commercial strains of Rhizobium phaseoli in soils containing indigenous strains of rhizobia and relatively high levels of $\mathrm{N}$. Inoculation resulted in significantly greater nodule numbers relative to indigenous soil strains, however significant seed yield increases were not found from the increase in inoculation.

A 2004 study by Henson and Halvorson at the North Dakota Agricultural Expt. Station Carrington Research Extension Center (Carrington, ND) and North Central Research Extension Center (Minot, ND) evaluated dry bean with seven levels of $\mathrm{N}$ without Rhizobium inoculation [22]. Additional treatment comparisons with and without inoculation at lower $\mathrm{N}$ levels and evaluation of the response to split $\mathrm{N}$ applications were studied. Soil test data $(0-61 \mathrm{~cm}$ depth $)$ indicated $17 \mathrm{~kg} \mathrm{NO}_{3}-\mathrm{N} \mathrm{ha}^{-1}$ at Carrington and $57 \mathrm{~kg} \mathrm{NO}_{3}-\mathrm{N} \mathrm{ha}^{-1}$ at Minot. An increase in seed yield was observed at Carrington as total $\mathrm{N}$ increased from 17 to 56 to $84 \mathrm{~kg} \mathrm{~N} \mathrm{ha}^{-1}$. Contrastingly, no significant $(\mathrm{p}<0.05)$ differences in seed yield were observed at Minot.

Nitrogen-limited conditions without extreme $\mathrm{pH}$ (not acidic or alkaline), no salinity and appropriate plant available water are considered necessary for symbiotic relationships between legumes and rhizobia, but the effects of $\mathrm{N}$ rich conditions on this symbiotic status remains poorly understood. Research conducted by Nanjareddy et al. [23] examined rhizobial symbiosis with dry bean under different $\mathrm{N}$ conditions. They found that high levels of $\mathrm{N}$ impaired nodule maturation and nodule numbers. Low $\mathrm{N}$ conditions increased nodule number, biomass, and extended the duration of $\mathrm{N}_{2}$-fixing activity, consistent with observations made by Edje et al. [10].

Scientists are exploring tools such as optical sensors to determine the need for in-season $\mathrm{N}$ application to increase $\mathrm{N}$ use efficiency (NUE). The overall NUE of a cropping system can be increased by achieving greater uptake efficiency from applied $\mathrm{N}$ inputs and reducing the amount of $\mathrm{N}$ lost from soil organic and inorganic $\mathrm{N}$ pools [24]. In order to maximize seed yield it is important to find an efficient $\mathrm{N}$ management system [25].

The chlorophyll carotenoid pigments in plant leaves absorb visible light from 400 to $700 \mathrm{~nm}$ for photosynthesis and reflect green light. Bullock and Anderson [26] found the Minolta SPAD 502 (SPAD) chlorophyll $\mathrm{N}$ meter reading to be 
useful as a diagnostic aid rather than a tool for $\mathrm{N}$ management in corn (Zea mays L.). The SPAD reading could provide a measure of the relative greenness of living leaves at a specific point in time and could possibly be useful in detecting $\mathrm{N}$ deficiencies in growing dry bean when compared to a non $\mathrm{N}$ limiting standard in the field.

Fritschi and Ray [27] assessed genotypic variation in soybean [Glycine max (L.) Merrill] chlorophyll content with the use of SPAD meter readings to see if these data could be used as a rapid screening method to predict genotypic variation in leaf tissue $\mathrm{N}$ content. They found that chlorophyll content was related to SPAD readings and leaf $\mathrm{N}$ content; however, the relationships found were not consistent for chlorophyll to be useful as a predictive tool for leaf $\mathrm{N}$ content in soybean. If SPAD readings were correlated to yield in dry bean, it could be a useful management tool.

The relationship between dry bean and strains of Rhizobium phaseoli bacteria associated with $\mathrm{N}$ fixation is highly variable and specific to environmental conditions. Dry hot weather conditions, periods of soil water saturation, and cold weather, will result in an inconsistency of the symbiotic relationship in supplying $\mathrm{N}$ nutrition during the growth cycle. No recent research in North Dakota has evaluated the effect of inoculum on the yield of the main dry bean classes grown in the state and the effect of fertilizer $\mathrm{N}$ on nodulation. Only about $19 \%$ of the surveyed growers in North Dakota used inoculum in 2010 [4].

The objectives of this dry bean research were to: 1) compare multiple types of inoculant and fertilizer management in relation to seed yield; 2) compare nodule formation among treatments and its association with seed yield; and 3) record observations on plant growth, utilizing visual scores, plant measurements, and optical sensors in order to better understand dry bean growth in relation to seed yield.

\section{Materials and Methods}

The experimental design was a RCBD $3 \times 2 \times 3$ factorial arrangement of cultivar, $\mathrm{N}$ fertility level, and inoculant treatment with four replicates. Three cultivars each from a different dry bean market class (black, navy, and pinto) were used: black, 'Eclipse' [28]; navy, 'Vista' (Gen-Tec Seeds Ltd., South Woodslee, ON, released 1989); and pinto, 'Lariat' [29]. The three market classes are the dominant classes in North Dakota and the cultivars the most commonly grown for a market class during the study period. There were two inoculant treatments alongwith a control (non-inoculated), Rhizobium leguminsarum bv. phaseoli $2 \times 10^{9}$ viable cells $\mathrm{g}^{-1}$ combined with Bacillus subtilis $2 \times 10^{8}$ viable spores $\mathrm{g}^{-1}$ (Hi-Stick, Becker Underwood Inc., Ames, Iowa), and Rhizobium legumnosarum bv. phaseoli $2 \times 10^{8}$ viable cells $\mathrm{g}^{-1}$ (RhizoStick, Becker Underwood Inc., Ames, Iowa). These peat-based inoculants were applied to seed prior to planting. In order to avoid inoculant treatment contamination, the non-inoculant treatments were planted first, then all plots containing RhizoStick were planted. After the plant- 
ing cones were sanitized, the cones were coated with HiStick and the remaining plots which contained HiStick were planted. There were two fertilizer treatments of no fertilizer (control) and $56 \mathrm{~kg} \mathrm{~N} \mathrm{ha}^{-1}$ in the form of urea at emergence. Pure live seeds were packaged to obtain the regionally recommended population of 222,400 plants ha ${ }^{-1}$ for Eclipse and Vista and 173,000 plants ha ${ }^{-1}$ for Lariat [30].

The cultivars were planted in four-row plots, $7.6 \mathrm{~m}$ long with a $45.7 \mathrm{~cm}$ row spacing. Plots were planted with a John Deere 71 flex four-row planter with a cone seed distribution system (John Deere, Moline, IL). Seeds were planted at a depth of 2.5 to $3.8 \mathrm{~cm}$. At all locations and years, the previous crop was wheat (Triticum aestivum L. emed. Thell.) and fields with a history of no recent dry bean production were chosen. The research was done at Prosper, ND, in 2010 and 2012. In 2013 and 2014, experiments were planted at Prosper and near Park River, ND, However, only the pinto cultivar was planted in 2014 and not the black or navy dry bean cultivars.

Soil tests were collected in the spring of the growing seasons (Table 1). Soil tests were conducted for nitrate- $\mathrm{N}\left(\mathrm{NO}_{3}-\mathrm{N}\right)$ at the NDSU Soil Testing Lab in Fargo, ND.

Dry nitrogen urea fertilizer (46-0-0) treatments were applied at emergence. Furrows were hoed about $5 \mathrm{~cm}$ deep and $5 \mathrm{~cm}$ to the side along each row, with the fertilizer hand spread into the furrows and immediately covered with soil.

Dimethenamid-P: (S)-2chloro-N-[(1-methyl-2-methoxy) ethyl]-N (2, 4-dimethylthien-3-yl)-acetamide (Outlook, BASF, Research Triangle Park, NC) was applied for weed control immediately after planting in all years and locations using a backpack sprayer with $8001 \mathrm{VS}$ nozzles at $275 \mathrm{KPa}$ at a rate of $941 \mathrm{~g} \mathrm{ha}^{-1}$. Hand weeding was conducted as needed during the season for additional weed control. On July $2^{\text {nd }}$ of 2014, Prosper and Park River were also sprayed with bentazon: (3-(1-methylethyl)-1H-2, 1, 3-benzothiadiazin-4 (3H)-one 2, 2-dioxide)) (Basagran, BASF, Research Triangle Park, NC) at $0.3 \mathrm{~L} \mathrm{ha}^{-1}$ of a.i. and imazamox: 2-(4,5-dihydro-4-methyl-4-(1-methylethyl)-5-oxo-1HOimidazol-2-yl)5-(methox ymethyl)-3-pyridinexarboxylic acid) (Raptor, BASF, Research Triangle Park,

Table 1. Soil test results for $\mathrm{NO}_{3}-\mathrm{N}$ at Prosper, ND, 2010, 2012, 2013 and Park River, ND, in 2013 and 2014.

\begin{tabular}{|c|c|c|c|c|c|c|c|c|c|c|}
\hline & & & \multicolumn{2}{|c|}{2010} & \multicolumn{2}{|c|}{2012} & \multicolumn{2}{|c|}{2013} & \multicolumn{2}{|c|}{2014} \\
\hline & & & \multicolumn{8}{|c|}{$\mathrm{cm}$} \\
\hline Location & $\begin{array}{l}\text { Latitude } \\
\text { Longitude }\end{array}$ & Soil Type ${ }^{\dagger}$ & $0-30.5$ & $30.5-61$ & $0-30.5$ & $30.5-61$ & $0-30.5$ & $30.5-61$ & $0-30.5$ & $30.5-61$ \\
\hline & & & \multicolumn{8}{|c|}{$\mathrm{kg} \mathrm{N} \mathrm{ha}^{-1}$} \\
\hline Prosper & $\begin{array}{l}47.00068 \\
-97.111\end{array}$ & $\begin{array}{l}\text { Kindred-Bearden } \\
\text { silty clay loam }\end{array}$ & 50 & 34 & 44 & 70 & 16 & 111 & 67 & 67 \\
\hline Park River & $\begin{array}{l}48.41168 \\
-97.671\end{array}$ & Fairdale silt loam & -- & -- & -- & -- & 38 & 16 & 55 & 41 \\
\hline
\end{tabular}

${ }^{\dagger}$ USDA soil survey data [31]. ${ }^{~}$ No experiment in 2010 and 2012. 
NC) at $8.4 \mathrm{~g} \mathrm{ha}^{-1}$ of a.i. In 2013 and 2014, preventative fungicide was applied using boscalid: (3-pyridinecarboxamide, 2-chloro-N-(4-chloro (1,1-biphenyl)-2-yl)) (Endura, BASF, Research Triangle Park, NC) at a rate of $539 \mathrm{~g} \mathrm{ha}^{-1}$ of a.i. during early reproductive growth stages.

A vigor score, scale of 1 - 9 with 9 being the most vigorous, was used during the growing season along with a visual greenness score, with a scale of $1-5$ with 5 being greener (Table 2). Chlorophyll readings on a scale from 0 to 99.9 with higher readings being greener, were taken with a handheld SPAD-502 meter (Spectrum Technologies, Aurora, IL). The SPAD readings were taken from the upper-most fully developed leaf and readings were averaged over 6 plants within the two center plot rows.

Root excavation was performed to count nodules per root two weeks after the R2 to R3 growth stage [32] (Table 2). Five plants per plot were extracted with shovels; the roots were cleaned in a bucket of water to remove soil before nodules were counted [33]. Plants for nodule counts were taken from the end of the two center plot rows before alleys were cut. Alleys were cut at the R5 growth stage in between the replicates, perpendicular to the planted plots, resulting in a harvested area of $6 \mathrm{~m} \times 1.8 \mathrm{~m}$. Plant height was measured before harvest from the soil surface to the upper main stem node of three random standing plants within the two center rows of every plot (Table 2). In 2010 and 2012, two rows per plot were harvested with a Hege 125B combine (Hege Company, Waldenberg, Germany). In 2013 and 2014 one row per plot was harvested by hand and threshed with a Hege $125 \mathrm{~B}$ combine. The harvested samples were dried to about $14 \%$ moisture content and cleaned (Allan Machine Company, Nevada, IA) to remove foreign material. All samples were weighed and analyzed for seed yield, moisture, and 1000 seed weight. Moisture and test weight were measured using a GAC 2100 moisture tester (DICKEY-John Corp., Minneapolis, MN) and

Table 2. Dates of application and observations for the cultivar, N-level, and rhizobacteria inoculant study conducted at two North Dakota locations from 2010 to 2014.

\begin{tabular}{|c|c|c|c|c|c|c|}
\hline \multirow[b]{2}{*}{ Measurement/Application } & \multicolumn{3}{|c|}{ Prosper, ND } & \multirow[b]{2}{*}{2014} & \multicolumn{2}{|c|}{ Park River, ND } \\
\hline & 2010 & 2012 & 2013 & & 2013 & 2014 \\
\hline Dry bean planted & 27 May & 17 May & 28 May & 29 May & 29 May & 24 May \\
\hline Applied fertilizer & 22 June & 1 June & 17 June & 18 June & 19 June & 18 June \\
\hline Vigor score & -- & -- & 8 Aug. & 9 July & 6 Aug. & 9 July \\
\hline Green score & -- & -- & 14 Aug. & 9 July & 6 Aug. & 9 July \\
\hline SPAD reading & -- & -- & $\mathrm{N} / \mathrm{A}$ & 9 July & $\mathrm{N} / \mathrm{A}$ & 9 July \\
\hline Root excavation/nodule count & 6 July & 10 July & 31 July & 7 Aug. & 1 Aug. & 1 Aug. \\
\hline Harvest & 20 Sept. & 18 Sept. & 2 Oct. & 26 Sept. & 3 Oct. & 23 Sept. \\
\hline
\end{tabular}


observations were adjusted to $13.5 \%$ moisture content. For the Lariat data an economic analysis was performed using a farm gate price for pinto beans in ND of $0.61 \mathrm{ct} \mathrm{kg}^{-1}$, which was multiplied by the yield to obtain the value in US \$ for each research unit. The inoculant treatment was valued at $\$ 24.70 \mathrm{ha}^{-1}$. The $50 \mathrm{~kg}$ $\mathrm{N} \mathrm{ha}{ }^{-1}$ was valued at $\$ 44.90$ and application cost of $\$ 11.12 \mathrm{ha}^{-1}$ (spreading of the fertilizer) was used. Cost of inoculant and or fertilizer + application cost, based on the treatment, was deducted from the price $\mathrm{x}$ yield number to obtain a dollar value for each research unit.

Weather data was obtained from the North Dakota Agricultural Weather Network [34].

Statistical analyses were conducted using standard procedures for a randomized complete block design. Data was analyzed as a factorial using analysis of variance with SAS 9.3 (SAS Institute Inc., Cary, NC). PROC MIXED procedure and Type 3 ANOVA tests were used to analyze treatment data. Each environment was analyzed separately. After testing for homogeneity of variance, research data with the complete set of treatments with all three cultivars from 2010 and 2012 at Prosper and Prosper and Park River 2013 were combined for analysis. In the combined analyses, the unique location and year combined into the term environment, and was considered a random effect in the sources of variation. Fixed effects in the analysis of this experiment were cultivar, inoculant, and application of $\mathrm{N}$ with all other factors considered random effects. All means were separated using a paired t-test at the $5 \%$ level of significance.

Additionally, due to Lariat only being planted in 2014 without the other two cultivars, the Lariat cultivar data from 2013 and 2014 at both Prosper and Park River was analyzed for each environment separately and combined across environments. All means were separated using a paired t-test at the $5 \%$ level of significance.

\section{Results and Discussion}

\subsection{Weather for Nitrogen Fertilization and Inoculation Effects on Dry Bean}

Air temperatures were close to historical 30-yr averages each year of this research; however, there was noticeable variation in rainfall (Table 3 and Table 4). There was above average rainfall during several month periods at Prosper recorded in July of $2010(103.4 \mathrm{~mm})$, and May $(105.2 \mathrm{~mm})$ and June $(192.5 \mathrm{~mm})$ of 2013. Park River had above average rainfall in August of 2014 (88.4 mm). These differences in rainfall may have impacted how the dry bean plants responded to each treatment and with heavy rainfall, root nodule activity may have been reduced.

\subsection{0, 2012, and 2013 Factorial Observing Effects on Cultivar, Nitrogen Fertilizer, and Inoculant}

\section{Cultivar}

The probability levels for significant factors for individual environments and 
Table 3. Monthly mean temperature and rainfall for Prosper, ND, in 2010, 2012, 2013 and 2014.

\begin{tabular}{|c|c|c|c|c|c|c|c|c|c|c|}
\hline \multirow{3}{*}{ Month } & \multicolumn{5}{|c|}{ Mean air temp. } & \multicolumn{5}{|c|}{ Mean rainfall } \\
\hline & 2010 & 2012 & 2013 & 2014 & Hist. $^{\dagger}$ & 2010 & 2012 & 2013 & 2014 & Hist. $^{\dagger}$ \\
\hline & \multicolumn{5}{|c|}{${ }^{\circ} \mathrm{C}$} & \multicolumn{5}{|c|}{$\mathrm{mm}$} \\
\hline May & 14 & 15 & 14 & 14 & 13 & 70 & 46 & 105 & 52 & 78 \\
\hline June & 19 & 20 & 20 & 20 & 19 & 81 & 67 & 193 & 107 & 100 \\
\hline July & 21 & 24 & 21 & 20 & 21 & 103 & 16 & 20 & 33 & 88 \\
\hline Aug. & 21 & 20 & 21 & 21 & 20 & 89 & 23 & 51 & 61 & 67 \\
\hline Sept. & 13 & 15 & 18 & 15 & 15 & 135 & 15 & 93 & 47 & 66 \\
\hline
\end{tabular}

$\dagger$ Historical data represents a 30-yr average from 1981-2010 (NDAWN, 2017).

Table 4. Monthly mean temperature and mean rainfall for Park River, ND, in 2013 and 2014.

\begin{tabular}{ccccccc}
\hline & \multicolumn{3}{c}{ Mean air temp. } & \multicolumn{3}{c}{ Mean rainfall } \\
\cline { 2 - 7 } Month & 2013 & 2014 & Hist. $^{\dagger}$ & 2013 & 2014 & Hist. $^{\dagger}$ \\
\cline { 2 - 6 } & \multicolumn{3}{c}{${ }^{\circ} \mathrm{C}$} & & \multicolumn{2}{c}{$\mathrm{mm}$} \\
\hline May & 12 & 13 & 14 & 253 & 63 & 70 \\
June & 19 & 18 & 19 & 85 & 134 & 88 \\
July & 21 & 19 & 21 & 71 & 41 & 86 \\
August & 20 & 20 & 20 & 23 & 88 & 63 \\
September & 16 & 15 & 15 & 50 & 31 & 47
\end{tabular}

†Historical data represents a 30-yr average from 1981-2010 (NDAWN, 2017). NDAWN station, about 17.5 km from Park River, ND, experiment site. (NDAWN, 2017).

all probabilities for the combined analysis are provided in Table 5.

For each environment and when the data from Prosper 2010, 2012, and 2013 along with Park River 2013 were combined, differences were found among the cultivars of dry bean for number of nodules plant ${ }^{-1}$, plant height, plant vigor, and 1000 seed weight (Table 6). On average the cultivar Lariat had more nodules plant $^{-1}$ (19) than both Eclipse (13) and Vista (9). At the various environments nodule numbers varied from 6 to 33 for Lariat, 5 to 28 for Eclipse, and 3 to 17 for Vista (Table 6).

Lariat was $3.6 \mathrm{~cm}$ taller than Vista; however, Eclipse did not differ in height from either cultivar. Lariat had a higher 1000 seed weight (300.6 g), typical for pinto bean, than the Eclipse (180.5 g) and Vista (169.3 g). Eclipse had a higher 1000 seed weight and number of nodules plant ${ }^{-1}$ than Vista when locations and years were combined (Table 6). At Prosper in 2010 Vista was yielding more than Eclipse and Lariat. At Prosper in 2012 Lariat yielded the highest (Table 6). Across all environments the seed yields were not significantly different at the 0.05 level, however the probability for differences in seed yield was 0.09 (Table 5). 
Table 5. Probability level for significant factors for nodules per plant ${ }^{-1}$, plant vigor, plant height, 1000 seed weight, and yield for 2010, 2012 and 2013 in Prosper, ND and 2013 at Park River, ND, and complete probabilities for combined analysis.

\begin{tabular}{|c|c|c|c|c|c|c|}
\hline \multirow{2}{*}{ Factor } & \multirow{2}{*}{ DF } & Nodules & Vigor & Height & 1000 seed weight & Yield \\
\hline & & \multicolumn{5}{|c|}{ Probability > F } \\
\hline \multirow{3}{*}{ Cultivar (Cvr) } & \multicolumn{6}{|c|}{ Prosper 2010} \\
\hline & 2 & 0.02 & $<0.0001$ & $<0.0001$ & $<0.0001$ & 0.01 \\
\hline & \multicolumn{6}{|c|}{ Prosper 2012} \\
\hline Cultivar (Cvr) & 2 & 0.03 & $<0.0001$ & $<0.0001$ & $<0.0001$ & 0.001 \\
\hline Fertilizer (Fert) & 1 & 0.03 & 0.95 & 0.69 & 0.69 & 0.49 \\
\hline \multirow[t]{2}{*}{ Cvr $\times$ Inoc $\times$ Fert } & 4 & 0.87 & 0.08 & 0.12 & 0.85 & 0.05 \\
\hline & \multicolumn{6}{|c|}{ Prosper 2013} \\
\hline Cultivar (Cvr) & 2 & 0.01 & 0.02 & $<0.0001$ & $<0.0001$ & 0.09 \\
\hline Cvr $\times$ Inoc & 4 & 0.53 & 0.01 & 0.27 & 0.78 & 0.72 \\
\hline Fertilizer (Fert) & 1 & 0.92 & 0.002 & 0.14 & 0.14 & 0.62 \\
\hline \multirow[t]{2}{*}{ Cvr $\times$ Inoc $\times$ Fert } & 4 & 0.53 & 0.01 & 0.75 & 0.30 & 0.70 \\
\hline & \multicolumn{6}{|c|}{ Park River 2013} \\
\hline Cultivar (Cvr) & 2 & $<0.0001$ & $<0.0001$ & 0.08 & $<0.0001$ & 0.49 \\
\hline Inoculant (Inoc) & 2 & 0.02 & 0.51 & 0.25 & 0.30 & 0.05 \\
\hline \multirow[t]{2}{*}{ Fertilizer (Fert) } & 1 & 0.02 & 0.20 & 0.003 & 0.003 & 0.97 \\
\hline & \multicolumn{6}{|c|}{ Prosper 2010, 2012, 2013 and Park River 2013 combined } \\
\hline Cultivar (Cvr) & 2 & $<0.0001$ & $<0.0001$ & 0.01 & $<0.0001$ & 0.09 \\
\hline Inoculant (Inoc) & 2 & 0.19 & 0.75 & 0.49 & 0.81 & 0.23 \\
\hline Cvr $\times$ Inoc & 4 & 0.48 & 0.38 & 0.78 & 0.38 & 0.68 \\
\hline Fertilizer (Fert) & 1 & 0.26 & 0.04 & 0.13 & 0.01 & 0.30 \\
\hline Cvr $\times$ Fert & 2 & 0.44 & 0.44 & 0.78 & 0.36 & 0.81 \\
\hline Inoc $\times$ Fert & 2 & 0.33 & 0.58 & 0.63 & 0.77 & 0.80 \\
\hline Cvr $\times$ Inoc $\times$ Fert & 4 & 0.90 & 0.40 & 0.73 & 0.33 & 0.45 \\
\hline Error & 255 & & & & & \\
\hline
\end{tabular}

In this research, only one cultivar per class was evaluated. Future research should look into the nodulation ability of more cultivars per class.

\section{Nitrogen}

Across cultivars and inoculants there were no seed yield differences with and without application of $\mathrm{N}$. Addition of $56 \mathrm{~kg} \mathrm{ha}^{-1} \mathrm{~N}$ reduced the number of nodules per plant at Prosper 2012 and Park River 2013 (Table 7). Addition of N increased the height of the plants and decreased the 1000 seed weight at Park River in 2013 (Table 7). When data was combined across locations, application of $56 \mathrm{~kg} \mathrm{~N} \mathrm{ha}^{-1}$ across all cultivars of dry bean had an increase in vigor score and decrease in 1000 seed weight (Table 7). The $\mathrm{N}$ applied may have put more of the 
Table 6. Mean trait values for nodules plant ${ }^{-1}$, plant vigor, plant height, 1000 seed weight, and yield averages of cultivars across inoculants and $\mathrm{N}$ treatments averaged over four environments: Prosper, ND, in 2010, 2012, 2013, and Park River, ND, in 2013.

\begin{tabular}{|c|c|c|c|c|c|}
\hline \multirow{2}{*}{ Cultivar } & Nodules plant $^{-1}$ & Vigor & Height & 1000 seed weight & Yield \\
\hline & Number & 1 to $9^{\dagger}$ & $\mathrm{cm}$ & g & $\mathrm{kg} \mathrm{ha}^{-1}$ \\
\hline & \multicolumn{5}{|c|}{ Prosper 2010} \\
\hline Eclipse & $8.1 b^{\ddagger}$ & $6.1 \mathrm{c}$ & $43.6 \mathrm{a}$ & $185.2 \mathrm{~b}$ & $1684 \mathrm{~b}$ \\
\hline Lariat & $12.0 \mathrm{a}$ & $7.9 \mathrm{a}$ & $39.3 \mathrm{~b}$ & $350.9 a$ & $1732 b$ \\
\hline Vista & $7.9 \mathrm{~b}$ & $6.6 \mathrm{~b}$ & $36.8 \mathrm{c}$ & $183.3 \mathrm{~b}$ & $1966 \mathrm{a}$ \\
\hline \multirow[t]{2}{*}{ LSD (0.05) } & 3.1 & 0.5 & 2.1 & 18.2 & 187.6 \\
\hline & \multicolumn{5}{|c|}{ Prosper 2012} \\
\hline Eclipse & $5.2 \mathrm{ab}$ & $5.2 \mathrm{~b}$ & $38.0 \mathrm{c}$ & $154.0 \mathrm{~b}$ & $3060 \mathrm{~b}$ \\
\hline Lariat & $6.3 \mathrm{a}$ & $7.0 \mathrm{a}$ & $56.2 \mathrm{a}$ & $263.0 \mathrm{a}$ & $3545 a$ \\
\hline Vista & $2.8 \mathrm{~b}$ & $4.3 \mathrm{~b}$ & $46.1 \mathrm{~b}$ & $141.5 b$ & $2655 b$ \\
\hline \multirow[t]{2}{*}{$\operatorname{LSD}(0.05)$} & 2.6 & 1.0 & 5.1 & 15.9 & 440 \\
\hline & \multicolumn{5}{|c|}{ Prosper 2013} \\
\hline Eclipse & $27.9 a$ & 6.6 & $53.7 \mathrm{a}$ & $203.6 \mathrm{~b}$ & 3705 \\
\hline Lariat & $33.2 \mathrm{a}$ & 6.5 & $44.8 \mathrm{~b}$ & $317.8 \mathrm{a}$ & 3557 \\
\hline Vista & $17.1 \mathrm{~b}$ & 7.3 & $47.0 \mathrm{~b}$ & $186.1 \mathrm{~b}$ & 3409 \\
\hline \multirow[t]{2}{*}{$\operatorname{LSD}(0.05)$} & 9.4 & ns & 3.0 & 27.5 & ns \\
\hline & \multicolumn{5}{|c|}{ Park River 2013} \\
\hline Eclipse & $10.4 \mathrm{~b}$ & $5.9 \mathrm{a}$ & 51.4 & $179.4 \mathrm{~b}$ & 2352 \\
\hline Lariat & $23.4 \mathrm{a}$ & $7.8 \mathrm{a}$ & 54.1 & $270.6 a$ & 2447 \\
\hline Vista & $9.0 \mathrm{~b}$ & $5.7 \mathrm{~b}$ & 50.2 & $166.4 \mathrm{c}$ & 2488 \\
\hline \multirow[t]{2}{*}{ LSD (0.05) } & 4.6 & 0.8 & $\mathrm{~ns}$ & 8.8 & ns \\
\hline & \multicolumn{5}{|c|}{ Combined } \\
\hline Eclipse & $12.9 \mathrm{~b}^{\neq}$ & $5.9 \mathrm{~b}$ & $46.7 \mathrm{ab}$ & $180.5 b$ & 2700 \\
\hline Lariat & $18.7 \mathrm{a}$ & $7.3 \mathrm{a}$ & $48.6 \mathrm{a}$ & $300.6 \mathrm{a}$ & 2820 \\
\hline Vista & $9.2 \mathrm{c}$ & $6.0 \mathrm{~b}$ & $45.0 \mathrm{~b}$ & $169.3 \mathrm{c}$ & 2651 \\
\hline LSD (0.05) & 2.8 & 0.4 & 2.2 & 9.8 & ns \\
\hline
\end{tabular}

${ }^{\dagger}$ Visual score $(1-9)$ with 1 being poor plant vigor and 9 indicating best plant vigor. ${ }^{*}$ Within columns, means followed by the same letter are not significantly different at $(\mathrm{p} \leq 0.05)$, $\mathrm{ns}=$ not significant.

Table 7. Nodules per plant, height, 1000 seed weight and plant vigor for $\mathrm{N}$ treatments for across cultivars and inoculants for Prosper 2012, Park River 2013 and four environments; Prosper, ND, in 2010, 2012, 2013, and Park River, ND, in 2013.

\begin{tabular}{|c|c|c|c|c|c|c|}
\hline & Prosper 2012 & \multicolumn{3}{|c|}{ Park River 2013} & \multicolumn{2}{|c|}{ Combined environments } \\
\hline $\mathrm{N}$ applied & Nodules plant $^{-1}$ & Nodules plant $^{-1}$ & Height & 1000 seed weight & Vigor & 1000 seed weight \\
\hline $\mathrm{kg} \mathrm{ha}^{-1}$ & Nodule Count & Nodule Count & $\mathrm{cm}$ & $\mathrm{g}$ & $1-9^{\dagger}$ & G \\
\hline 0 & $6.0 \mathrm{a}$ & $16.3 \mathrm{a}$ & $49.7 \mathrm{~b}$ & $210.6 \mathrm{a}$ & $6.2 b^{\ddagger}$ & $221.8 \mathrm{a}$ \\
\hline 56 & $3.6 \mathrm{~b}$ & $12.2 \mathrm{~b}$ & $54.1 \mathrm{a}$ & $200.3 b$ & $6.6 \mathrm{a}$ & $211.8 \mathrm{~b}$ \\
\hline $\operatorname{LSD}(0.05)$ & 2.2 & 3.4 & 2.9 & 6.6 & 0.3 & 8 \\
\hline
\end{tabular}

$\dagger$ Visual score $(1-9)$ with 1 being poor plant vigor and 9 indicating best plant vigor. $\ddagger$ Within columns, means followed by the same letter are not significantly different at $(\mathrm{p} \leq 0.05)$. 
Table 8. Seed yield and nodule count for inoculants across N levels and cultivars of dry bean at Park River, ND, in 2013.

\begin{tabular}{ccc}
\hline \multirow{2}{*}{ Inoculant } & Yield & Nodules per plant \\
\cline { 2 - 3 } & $\mathrm{kg} \mathrm{ha}^{-1}$ & Nodule Count \\
\hline None & $2317 \mathrm{~b}^{\dagger}$ & $10.7 \mathrm{~b}$ \\
HiStick & $2599 \mathrm{a}$ & $16.2 \mathrm{a}$ \\
RhizoStick & $2364 \mathrm{ab}$ & $15.8 \mathrm{a}$ \\
LSD (0.05) & 238 & 4.2 \\
\hline
\end{tabular}

$\dagger$ Within columns, means followed by the same letter are not significantly different at $(\mathrm{p} \leq 0.05)$.

plants' energy toward vegetative growth or possibly more pods, causing a lower 1000 seed weight as less energy would be going towards pod fill.

\section{Inoculant}

At Park River in 2013, the addition of inoculant had an increase in yield for the HiStick inoculant compared to the control but it was not different in yield with the RhizoStick inoculant (Table 8). The slightly higher yield from HiStick may be related to the Bacillus subtilis in the product, which has natural antifungal properties, or could be related to the slightly higher cell count $\mathrm{g}^{-1}$ of $R h i$ zobium leguminsarum bv. phaseoli compared to RhizoStick. There were nodules on the control (no inoculant) that indicates natural rhizobacteria in the soil (Table 8). Combined across four environments $(2010,2012$, and 2013) the main effect "inoculants" did not show significant differences for the traits measured (Table 5).

\subsection{Cultivar Lariat 2013 and 2014 Agronomic and Economic Observations}

The following section is describing the pinto cultivar Lariat with inoculant and N application at Prosper and Park River in 2013 and 2014, Eclipse and Vista were not tested in these experiments.

\section{SPAD Readings}

Application of $\mathrm{N}$ resulted in differences in the green score and SPAD readings at Park River in 2013 and 2014, Prosper 2014 and across the environments (Table 9).

The SPAD readings were objective measurements, while visual green score was subjective. Observations at Park River indicated an increase in green score in both 2013 and 2014 with addition of $\mathrm{N}$ fertilizer; however, the SPAD readings showed no difference between $\mathrm{N}$ treatments in 2014 (Table 10).

The lack of consistency between green score and SPAD readings may be caused by the method used for SPAD readings, as readings were taken from the uppermost developed leaf and may not have been representative of the whole plant. Park River in 2013 showed a decrease in green score and SPAD reading with application of $\mathrm{N}$. The combined results indicate that the plants were greener 
Table 9. Probability level for significant factors for visual green score and SPAD observations for Lariat 2013 and 2014 in Prosper and Park River, ND, and combined across environments.

\begin{tabular}{|c|c|c|c|}
\hline & & Green & Spad \\
\hline Factor & $\mathrm{DF}$ & \multicolumn{2}{|c|}{ Probability $>$ F } \\
\hline & \multicolumn{3}{|c|}{ Park River 2013} \\
\hline Fertilizer (Fert) & 1 & 0.01 & 0.03 \\
\hline Inoculant (Inoc) & 2 & 0.75 & 0.06 \\
\hline \multirow[t]{2}{*}{ Fert $\times$ Inoc } & 2 & 0.16 & 0.03 \\
\hline & \multicolumn{3}{|c|}{ Park River 2014} \\
\hline Fert & 1 & 0.01 & 0.08 \\
\hline Inoc & 2 & 0.16 & 0.01 \\
\hline \multirow[t]{2}{*}{ Fert $\times$ Inoc } & 2 & 0.95 & 0.80 \\
\hline & \multicolumn{3}{|c|}{ Prosper 2013} \\
\hline Fert & 1 & 0.07 & 0.31 \\
\hline Inoc & 2 & 0.62 & 0.48 \\
\hline \multirow[t]{2}{*}{ Fert $\times$ Inoc } & 2 & 0.62 & 0.26 \\
\hline & \multicolumn{3}{|c|}{ Prosper 2014} \\
\hline Fert & 1 & 0.01 & 0.39 \\
\hline Inoc & 2 & 0.81 & 0.58 \\
\hline \multirow[t]{2}{*}{ Fert $\times$ Inoc } & 2 & 0.54 & 0.49 \\
\hline & \multicolumn{3}{|c|}{ Combined } \\
\hline Fert & 2 & 0.03 & 0.05 \\
\hline Inoc & 2 & 0.89 & 0.43 \\
\hline Fert $\times$ Inoc & 4 & 0.70 & 0.86 \\
\hline Error & 87 & & \\
\hline
\end{tabular}

Table 10. Visual green score and SPAD readings of Lariat pinto bean across inoculants at Prosper and Park River, ND, in 2013 and 2014 and combined.

\begin{tabular}{ccccccccccc}
\hline & \multicolumn{3}{c}{ Prosper } & \multicolumn{3}{c}{ Park River } & \multicolumn{3}{c}{ Combined } \\
\hline & \multicolumn{2}{c}{ Green $^{\dagger}$} & \multicolumn{2}{c}{ SPAD $^{\ddagger}$} & \multicolumn{2}{c}{ Green } & SPAD & Green & SPAD \\
\hline N applied & 2013 & 2014 & 2013 & 2014 & 2013 & 2014 & 2013 & 2014 & $2013-2014$ \\
$\mathrm{~kg} \mathrm{ha}^{-1}$ & $1-5$ & $0-99.9$ & & $1-5$ & $0-99.9$ & $1-5$ & $0-99.9$ \\
0 & 4.2 & $3.6 \mathrm{~b}^{\S}$ & 44.5 & 40.8 & $4.0 \mathrm{a}$ & $2.9 \mathrm{~b}$ & $41.6 \mathrm{a}$ & 39.1 & $3.7 \mathrm{~b}$ & $41.5 \mathrm{a}$ \\
56 & 4.6 & $4.1 \mathrm{a}$ & 43.8 & 40.0 & $3.3 \mathrm{~b}$ & $4.1 \mathrm{a}$ & $39.7 \mathrm{~b}$ & 37.0 & $4.0 \mathrm{~b}$ & $40.1 \mathrm{~b}$ \\
$\mathrm{LSD}(0.05)$ & $\mathrm{ns}$ & 0.4 & $\mathrm{~ns}$ & $\mathrm{~ns}$ & 0.6 & 0.8 & 1.7 & $\mathrm{~ns}$ & 0.3 & 1.3 \\
\hline
\end{tabular}

$\dagger$ Visual score $(1-5)$ with 1 as lighter green and 5 as darker green. $\ddagger$ SPAD readings $(0-99.9)$ with higher readings representing darker green. $₫$ Within columns, means followed by the same letter are not significantly different at $(\mathrm{p} \leq 0.05), \mathrm{ns}=$ not significant. 
with the application of $\mathrm{N}$ but the SPAD score was lower. Differences in green score and SPAD between inoculants were recorded only in 2014 at Park River (Table 11). The seed with HiStick had the lowest SPAD score and significantly lower than no inoculant, but seed with RhizoStick was not different from no inoculant or the HiStick application. In contrast, in 2013 the HiStick inoculant without $\mathrm{N}$ had a higher SPAD score than the no inoculant without $\mathrm{N}$, however the RhizoStick with $56 \mathrm{~kg} \mathrm{~N} \mathrm{ha}^{-1}$ had a higher SPAD reading compared with no inoculant with the application of $\mathrm{N}$ (Table 11).

SPAD reading indicated differences in greenness of dry bean plant leaves, but the method used in this study was not consistently representative of the color of the whole plant as the SPAD reading did not always match the visual observation. The method involving observation of the uppermost fully developed leaf may need to be improved upon, and more research using a SPAD meter as a management tool in dry bean could be useful. Utilizing other imagery technologies such as NDVI may be more successful for in-season fertilizer recommendations.

Although no significant difference in yield or nodule count was found for the main effects $\mathrm{N}$, inoculation, or the interaction, the trends were higher yield with $\mathrm{N}$ application, more nodules with RhizoStick and lower nodule numbers with addition of $\mathrm{N}$ (Table 12). Eckert et al. [18] also noted a non-significant trend for higher dry bean yield with the application of $56 \mathrm{~kg} \mathrm{~N} \mathrm{ha}^{-1}$ in North Dakota. The RhizoStick tended to have higher nodule numbers and higher yield compared to the no inoculant control. This would warrant to further investigate the effect of both $\mathrm{N}$ rate, source and application timing in combination with a Rhizobia inoculant.

\section{Economics}

When observing each individual year and location, a clear best management practice for $\mathrm{N}$ fertilizer does not emerge. Economic factors tend to drive production practices. Table 12 includes data combined across 2013 and 2014 from Park River and Prosper for the pinto variety Lariat and includes information on net

Table 11. SPAD readings of Lariat pinto bean for two $\mathrm{N}$ rates and across $\mathrm{N}$ rates at Park River, ND, in 2013 and 2014.

\begin{tabular}{cccc}
\hline & \multicolumn{2}{c}{ Park River 2013 } & Park River 2014 \\
\cline { 2 - 3 } & $0 \mathrm{~kg} \mathrm{~N} \mathrm{ha}^{-1}$ & $56 \mathrm{~kg} \mathrm{~N} \mathrm{ha}^{-1}$ & \\
\hline Inoculant & \multicolumn{2}{c}{ SPAD $\dagger$} & \\
None & $39.9 \mathrm{bcd}^{\ddagger}$ & $38.9 \mathrm{~cd}$ & $40.2 \mathrm{a}^{\S}$ \\
HiStick & $43.4 \mathrm{a}$ & $38.3 \mathrm{~d}$ & $35.6 \mathrm{~b}$ \\
RhizoStick & $41.6 \mathrm{abc}$ & $42.0 \mathrm{ab}$ & $38.4 \mathrm{ab}$ \\
LSD (0.05) & & & 3.5 \\
\hline
\end{tabular}

${ }^{\dagger}$ SPAD readings $\left(0\right.$ - 99.9) with higher readings representing darker green. ${ }^{*}$ Comparing any means in the two fertilizer rate columns followed by the same letter are not significantly different at $(\mathrm{p} \leq 0.05)$. ${ }^{5}$ Within the column, means followed by the same letter are not significantly different at $(\mathrm{p} \leq 0.05)$. 
Table 12. Lariat dry bean seed yield and nodules per plant for applied $\mathrm{N}$ and inoculant for 2013 and 2014 at Park River and Prosper, ND, combined across environments.

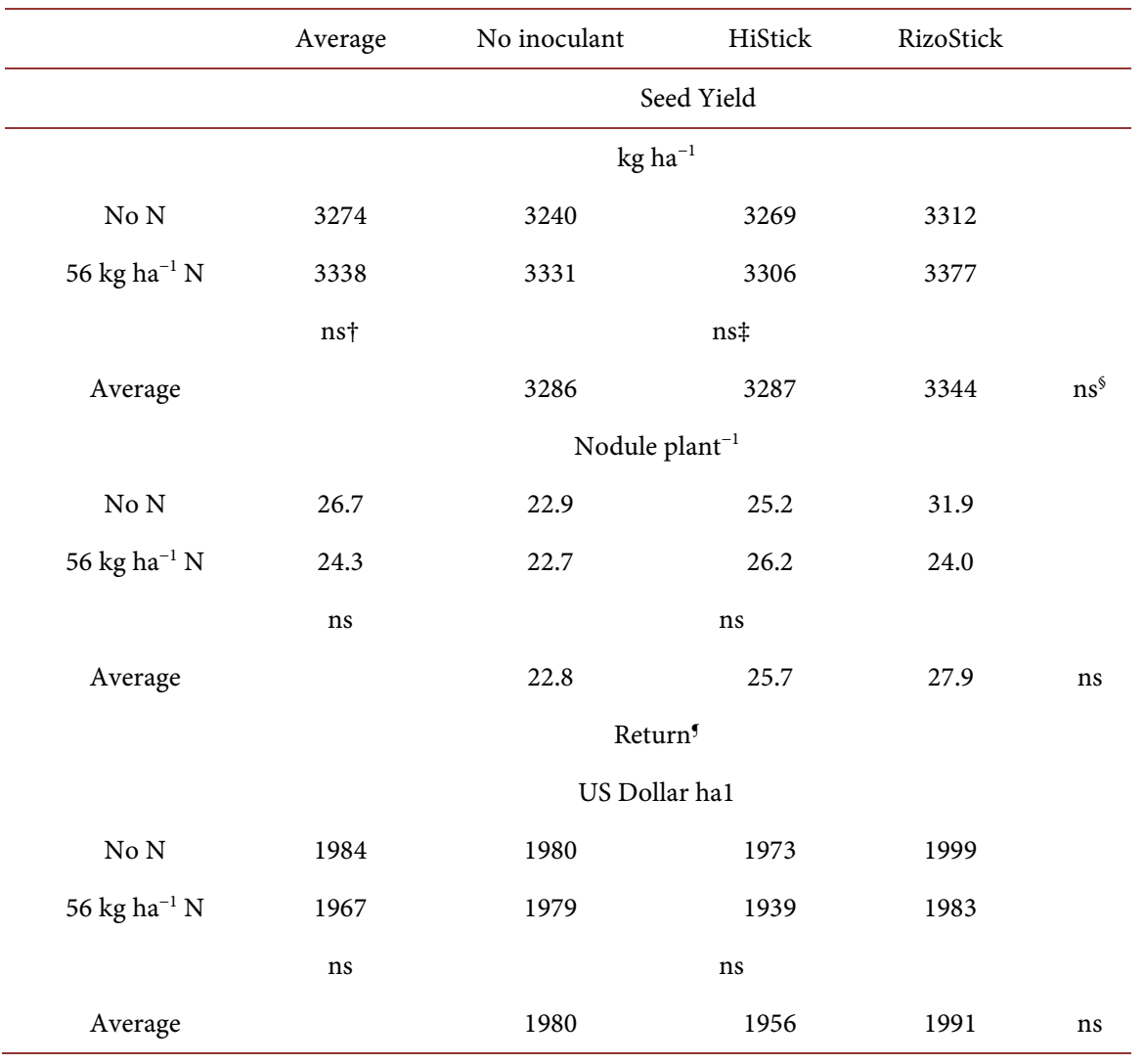

$\dagger \mathrm{ns}$, within columns is not significantly different at $(\mathrm{p} \leq 0.05)$. $\ddagger$ Comparing any means in the three inoculant columns followed by the same. ${ }^{5}$ Comparing means within the row. 'Pinto bean $0.61 \mathrm{ct} \mathrm{kg}^{-1}$, inoculant $\$ 24.70 \mathrm{ha}^{-1}, 50 \mathrm{~kg} \mathrm{~N} \mathrm{ha}^{-1}$ was valued at $\$ 44.90$, and fertilizer application cost of \$11.12 $\mathrm{ha}^{-1}$.

return. Net return was calculated by using current prices for inoculant and fertilizer. The return is only comparing the inoculant and $\mathrm{N}$ inputs and does not consider unrelated costs such as seed, fuel, or chemical costs.

In this analysis, it shows that with the input costs of fertilizer compared to inoculant there are no significant differences and no significant differences among inoculant treatments. One major factor to consider is the initial $\mathrm{N}$ content of the soil (Table 1). It might be possible that under $\mathrm{N}$ deficient conditions there might be yield differences among the treatments. In production practices, before making a fertilizer management strategy, all conditions should be considered including existing $\mathrm{N}$, prior rhizobacteria inoculation within field, and economic variables. Future research observing $\mathrm{N}$ deficient conditions would be insightful.

\section{Conclusions}

Across locations there was no $\mathrm{N}$ management practice that increased seed yield consistently among the different locations and under varying weather conditions. Application of $\mathrm{N}$ did not result in differences in yield, which conflicted with the results of Edje et al. [10], who documented a yield increase due to $\mathrm{N}$ 
application but are consistent with the observations by Eckert et al. [18] conducting $\mathrm{N}$ research in North Dakota. Addition of fertilizer reduced nodule count by $40 \%$ and $25 \%$ at Prosper in 2012 and Park River in 2013, respectively. Although adding $\mathrm{N}$ did not increase seed yield, soil available $\mathrm{N}$ and rhizobacteria already in the soil may have been confounding factors. Cultivars differed in number of nodules, yield, height, and 1000 seed weight when averaged over four environments but the combined data did not show that interactions occurred among cultivar and inoculant and fertilizer factors.

The results of this study indicate that best management practices for dry bean $\mathrm{N}$ management will depend on location and environmental conditions. In farmer's fields it may be beneficial to observe test strips of dry bean with and without inoculant and depending on soil $\mathrm{N}$ levels looking at varying levels of fertilizer applications, and adjust future management of fields on observed yield differences.

\section{References}

[1] United States Department of Agriculture (USDA) (2017) Quick Stats 2.0. U.S. Department of Agriculture, National Agricultural Statistics Service, Washington DC. https://quickstats.nass.usda.gov/

[2] Franzen, D. (2006) Fertilizing Pinto, Navy, and Other Dry Edible Beans. NDSU Ext. Serv. SF 720. North Dakota Agric. Exp. Station, Fargo, ND.

[3] Franzen, D. (2013) Dry Bean Fertility. In: Dry Bean Production Guide, Bull. A-1133, NDSU Ext. Serv., Fargo, 18-23.

[4] Knodel, J., Luecke, J., Beauzay, P., Franzen, D., Kandel, H., Markell, S., Osorno, J.M. and Zollinger, R. (2011) 2010 Dry Bean Grower Survey of Pest Problems and Pesticide Use in Minnesota and North Dakota. NDSU Ext. Serv. Bull. No. E-1522.

[5] Fageria, N.K. and Santos, A.B. (2008) Yield Physiology of Dry Bean. Journal of Plant Nutrition, 31, 983-1004. https://doi.org/10.1080/01904160802096815

[6] Stevens, B. and Belden, K. (2005) Nutrient Management Guidelines for Dry Beans. Reg. Bull. B-1016R. Coop. Ext. Serv. and Coll. of Ag. Uni. of Wyoming, Laramie.

[7] Wetzel, R.G. and Likens, G.E. (1991) Inorganic Nutrients: Nitrogen, Phosphorus, and Other Nutrients. In: Wetzel, R.G. and Likens, G.E., Eds., Limnological Analyses, Springer-Verlag, New York. https://doi.org/10.1007/978-1-4757-4098-1_7

[8] Havlin, J.L., Beaton, J.D., Tisdale, S.L. and Nelson, W.L. (2005) Nitrogen. In: Yarnell, D., Yehle, K., Kiefer, J. and Carnis, M., Eds., Soil Fertility and Fertilizers, Pearson Education Inc., Upper Saddle River, 97-112.

[9] Schoenau, J. (2016) Fertility Requirements and Contributions of Pulse Crops. http://proof.saskpulse.com/files/general/160205_Schoenau_2016_Sask_Pulse_Tour_ fertility_presentation.pdf

[10] Edje, O., Mughogho, L. and Ayonoadu, U. (1975) Responses of Dry Beans to Varying Nitrogen Levels. Agronomy Journal, 67, 251-255. https://doi.org/10.2134/agronj1975.00021962006700020020x

[11] O’Leary, M., Rehm, G. and Schmitt, M. (2002) Understanding Nitrogen in Soils. Univ. of Minnesota, Coop Ext. Serv.

http://www.extension.umn.edu/agriculture/nutrient-management/nitrogen/underst anding-nitrogen-in-soils/ 
[12] Brady, N. and Weil, R. (2010) Nutrient Cycles and Soil Fertility. In: Anthony, V.R., Ed., Elements of the Nature and Properties of Soils, 3rd Edition, Pearson Education Inc, Upper Saddle River, NJ, 396-420.

[13] Graham, P.H. (1978) Some Problems and Potentials of Field Beans Phaseolus vulgaris in Latin America. Field Crops Research, 1, 295-317.

[14] Farid, M. and Navabi, A. (2015) N2 Fixation Ability of Different Dry Bean Genotypes. Canadian Journal of Plant Science, 95, 1243-1257. https://doi.org/10.4141/CJPS-2015-084

[15] Hungria, M. and Vargas, M.A.T. (2000) Environmental Factors Affecting $\mathrm{N}_{2}$ Fixation in Grain Legumes in the Tropics, with an Emphasis on Brazil. Field Crops Research, 5, 151-164.

[16] Graham, P.H. (1981) Some Problems of Nodulation and Symbiotic Nitrogen Fixation in Phaseolus vulgaris L.: A Review. Field Crops Research, 4, 93-112.

[17] Kipe-Nolt, J.A., Vargas, H. and Giller, K.E. (1993) Nitrogen Fixation in Breeding Lines of Phaseolus vulgaris L. Plant Soil, 152, 103-106. https://doi.org/10.1007/BF00016338

[18] Eckert, F.R., Kandel, H.J., Johnson, B.L., Rojas-Cifuentes, G.A., Deplazes, C., Vander Wal, A.J. and Osorno, J.M. (2011) Row Spacing and Nitrogen Effects on Upright Pinto Bean Cultivars under Direct Harvest Conditions. Agronomy Journal, 103, 1314-1320. https://doi.org/10.2134/agronj2010.0438

[19] Kellman, A.W., Hill, G.D. and McKenzie, B.A. (2005) Variability in Nodulation of Phaseolusvulgaris L. with Different Rhizobial Strains. Agron. New Zealand, 35, 57-65.

[20] Fageria, N.K., Melo, L.C., Ferreira, E.P.B., Oliveira, J.P. and Knupp, A.M. (2014) Dry matter, Grain Yield, and Yield Components of Dry Bean as Influenced by Nitrogen Fertilization and Rhizobia. Communications in Soil Science and Plant Analysis, 45, 111-125. https://doi.org/10.1080/00103624.2013.848877

[21] Weiser, G.C., Grafton, K.F. and Berryhill, D.L. (1985) Nodulation of Dry Beans by Commercial and Indigenous Strains of Rhizobium phaseoli. Agronomy Journal, 77, 856-859. https://doi.org/10.2134/agronj1985.00021962007700060007x

[22] Henson, B. and Halvorson, M. (2004) Dry Bean Response to Nitrogen Fertilizer. https://www.ag.ndsu.edu/archive/carringt/agronomy/Research/Fertility/04\%20DEB \%20Response\%20to\%20N.pdf

[23] Nanjareddy, K., Blanco, L., Arthikala, M.K., Affantrange, X.A., Sanchez, F. and Lara, M. (2014) Nitrate Regulates Rhizobial and Mycorrhizal Symbiosis in Common Bean (Phaseolus vulgaris L.). Journal of Integrative Plant Biology, 56, 281-298. https://doi.org/10.1111/jipb.12156

[24] Cassman, K.G., Dobermann, A. and Walters, D.T. (2002) Agroecosystems, Nitrogen-Use Efficiency, and Nitrogen Management. $A M B I O, 31,132-140$. https://doi.org/10.1579/0044-7447-31.2.132

[25] Davis, J.G. and Brick, M.A. (2009) Fertilizing Dry Beans. Colorado State Univ. Ext. Fact Sheet No. 0539.

[26] Bullock, D.G. and Anderson, D.S. (2008) Evaluation of the Minolta SPAD-502 Chlorophyll Meter for Nitrogen Management in Corn. Journal of Plant Nutrition, 21, 741-755. https://doi.org/10.1080/01904169809365439

[27] Fritschi, F.B. and Ray, J.D. (2007) Soybean Leaf Nitrogen, Chlorophyll Content, and Chlorophyll a/b Ratio. Photosynthetica, 45, 92-98. https://doi.org/10.1007/s11099-007-0014-4 
[28] Osorno, J.M., Grafton, K.F., Rasmussen, J.B., Rojas-Cifuentes, G.A., Gelin, R. and Vander-Wal, A.J. (2009) Release of "Eclipse" Black Bean. Bean Improvement Cooperative. Annual Report, Vol. 52, 160-161.

[29] Osorno, J.M., Grafton, K.F., Rojas-Cifuentes, G.A., Gelin, R. and Vander Wal, A. (2010) Registration of "Lariat" and "Stampede" Pinto Beans. Journal of Plant Registrations, 4, 5-11. https://doi.org/10.3198/jpr2009.03.0143crc

[30] Kandel, H. (2013) Drybean Production Guide. Bull. No. A-1133 (Revised). NDSU Ext. Serv., Fargo.

[31] United States Department of Agriculture (USDA) (2017). http://websoilsurvey.nrcs.usda.gov/app/WebSoilSurvey.aspx

[32] LeBaron, M.J. (1974) Developmental Stages of the Common Bean Plant; A Description. Univ. of Idaho, Coop Ext. Serv. No. 228.

[33] Penn State College of Agricultural Sciences (2012) Common Bean Shovelomics. http://plantscience.psu.edu/research/labs/roots/methods/field/shovelomics/intensiv e-bean-crown-phenotyping

[34] NDAWN. North Dakota Agricultural Weather Network (2017) North Dakota State Univ., Fargo. http://ndawn.ndsu.nodak.edu 